\title{
Investigation of Causal Correlations Between Higher Education Development and Economic Growth in Vietnam
}

\author{
Nguyen Duc Hanh ${ }^{1}$, Bui Manh Dung ${ }^{2}$ \\ ${ }^{1}$ VNU University of Education, Hanoi, Vietnam \\ 2 Tan Trao University, Tuyen Quang, Vietnam \\ Correspondence: Nguyen Duc Hanh, VNU University of Education, Hanoi, Vietnam. E-mail duchanh.xafs@gmail.com
}

Received: March 14, $2021 \quad$ Accepted: April 6, $2021 \quad$ Online Published: April 25, 2021

doi:10.5539/res.v13n2p83 URL: https://doi.org/10.5539/res.v13n2p83

\begin{abstract}
This work investigated the dynamic relationship between higher education and economic growth in Vietnam using annual data collected ten years from 2010 to 2019. The auto-regressive distributive lag framework was used along with the error correction term to investigate the long-run relationship between real gross domestic product, enrollment in higher education, gross capital formation, and labor. The study used the Granger causality test to assess the relationship between higher education and economic expansion. Follow as the test results, a unidirectional causality running from higher education to economic growth have observed. The necessary diagnostic tests have applied to check the reliability and acceptability of model outputs, and they have been found suitable.
\end{abstract}

Keywords: auto-regressive distributive lag framework, bounds test, error correction term, Granger causality, higher education

\section{Introduction}

A high rate of economic growth is one of the foremost aims of all nations. For an extended period, researchers have been the argument that physical capital matters more for economic growth. However, contemporary research on the subject matter indicates other dimensions of capital, such as human capital, as a source of economic increase. According to Becker (1964), Rusli and Hamid (2014), and Devada (2015), human capital is the critical factor in the economic growth attempt of a nation. It is the skills, knowledge, and experience possessed by an individual (Bergheim, 2005). One of the sources from which an individual obtains these essential resources is educational institutions. Therefore, educational institutions can play a significant role in the economic progress of nations. This statement is reflected in 2006 by Mr Kofi Annan, the former United Nations secretary-general. He argued that Asia's primary driver, Africa's development in the 21 st century, must be the university.

Skills and knowledge can be developed by attaining a formal educational system in response to which developing countries are expanding educational opportunities. Vietnam is not an exception where expansion in higher education and educational reforms is an important task, especially the third education reform in 1979 (Thuy Linh, 2017). Vietnam's national education policies such as the Party's central resolution 29, in 2013, the new higher education law in 2018, orientation the higher education to feed the demand of a growing economy and to realize the dream of joining the high middle-income group by 2025 (Dang Duc Anh, 2019).

Despite tertiary education in Vietnam being even not a century old, enrollment has increased significantly. According to a report from the Ministry of Education and Training (2020), from 1997/1998 to 2018/2019, it has raised more than 3.3 fold $(123,969$ in $1997 / 1998$ to 413,277 in 2018/2019), so after twenty years, enrollment in tertiary education rose more than three times, as Education Statistics Annual Abstract in Vietnam, 2019/2020. Over the period elapsing between 2009 and 2013, nearly half of general government expenditure on education to finance tertiary education (UNESCO, 2019). In the same way, there is also observed expansion in tertiary education institutions. Look at the number of universities and colleges. There are 295 universities and colleges in the country in 2009, and it currently is 460 (Nguyen Duc Hanh, 2020). In a nutshell, all these facts indicate that higher education has been given due attention in Vietnam.

Have some of the different ways higher education can contribute to a country's economic growth, and these are increased productivity and income, increased capability, and institutional improvements. Endogenous growth theories since the 1990s have emerged with a theoretical explanation for the contribution of higher education to economic growth. They argued that highly skilled personnel are required for technology adaptation and transfer and, at the same time, increase 
efficiency and productivity of the economy (Lucas, 1988). Endogenous growth theories also stress non-market private benefits like improved health and reduced family size as a component of the capability approach to growth resulting from higher education. Moreover, higher education results also in non-market social benefits like democratic institutions and political stability. As to the World Bank Group (2017), higher education can reduce poverty and encourage shared property.

However, it is impossible to recommend a particular country engage in expansion of higher education to bring about economic growth in light of the above arguments because there is empirical evidence that shows the absence of a significant relationship between education and economic development (Temple, 1999), (Bils and Klenow, 2000), (Pritchett, 2000), (Hadushek, Woessmann, 2007), and (Horii et al., 2008). Despite the need to investigate whether endogenous growth theory fits in Vietnam, however so far, still no prior studies above problems were undertaken in Vietnam. Therefore, this study is to determine whether there is a causal relationship between economic growth and higher education in Vietnam. Thus, the study hypothesizes the following (1) There is a long-run relationship between higher education and Vietnam's economic growth. (2) There is no dynamic causality running from higher education to the economic development of Vietnam.

\section{Contents}

\subsection{Material and Method}

To serve research purposes, a time series data spanning from 2010 to 2019 collected from available sources on four variables such as real GDP, enrollment in higher education, working-age population, and gross capital formation. Real GDP used as a proxy for the economic growth of the country (World Bank Group, 2019; World Bank Group, 2019; GDP-World Development Indicators: Structure of output, 2019). Enrollment in higher education (number) used to representation higher education. A few data values were missing in the period, but they are filled by the interpolation method. The working-age population used to delegation labor, and gross capital formation is used to proxy physical capital. The available literature supports the choice of the variables and the corresponding representations used. Real GDP, labor, and enrollment in higher education were accessed from the World Bank indicator, while gross capital formation was obtained from the Vietnam Ministry of Finance. This work has used EViews version 9 for estimation and tests in calculation and data analysis.

\subsection{The Model}

This study used the neoclassical growth model developed by Solow (1956) and extended by endogenous growth models Romer (1989) and Lucas (1988). According to the model, relying on Coup Douglas production function, the national income is the function of factors of productions like physical capital and labor as introduced initially and human capital as latter incorporated. Keeping the former two inputs in place, we replace the human capital variable with the enrollment higher education variable.

$$
Y=T H^{\gamma} P^{\alpha} L^{\beta} \text {. }
$$

Where $Y$ is real GDP, $T$ is technological progress, $P$ is physical capital, $L$ is labor, and $H$ is a human capital variable, and $\gamma$, $\alpha$, and $\beta$ are parameters. Following proxies for the variables indicated above, equation (1) can be written as

$$
Y=T E \gamma S^{\alpha}\left(L^{f}\right)^{\beta} .
$$

In equation (2), $E$ is Enrollment in Higher Education (EHE), $S$ is Gross Capital Formation (GCF), $L^{f}$ is labor force.

Taking natural logarithm to both sides of the equations (1), (2), we received

$$
\ln Y=\ln T+\gamma \ln E+\alpha \ln S+\beta \ln L^{f} .
$$

Then the time series econometric model representation of the equation (3) is

$$
\ln Y_{t}=\ln T+\gamma \ln E_{t}+\alpha \ln S_{t}+\beta \ln L_{t}^{f}+\varepsilon_{i} .
$$

With $\mathrm{t}$ is the time period, and $\varepsilon_{\mathrm{i}}$ is the disturbance term.

In case variables considered are integrated of a different order but not integrated of order two $I(2)$ and more, there are no competing models than ARDL (Pesaran and Shin, 1996). The model was initially developed by Pesaran et al. (2001) and got popularity over other alternative models because: (1) It can be applied even though variables are integrated into a different order. That is some integrated of order zero, and some integrated of order one; (2) It can be used for small sample size; (3) It guarantees no worry about serial correlation (Nkoro and Uko, 2016). The estimation of ARDL usually involves three steps: Firstly, a unit root test should be applied to ascertain that none of the variables is I(2) or more. Then co-integration test drawing on the bound test should be used to check for long-run relationships. Finally, we analyze the causality between extending higher education and economic growth. 


\subsection{Unit Root Test}

To avoid spurious regression, we should be care taken of when dealing with time-series data. Spurious regression leads to results not suitable as the dependent variable regressed over a set of explanatory variables lacking constant means and variance. To overcome, we need to test data on the variables for unit root and, once detected, take appropriate measures, and the most often used remedy is differencing. There are alternative techniques for testing unit root and Augmented Dicky Fuller, which was developed by Dickey and Fuller (1979), utilized for this study and given as follows

$$
\Delta Y_{t}=\beta_{1}+\beta_{2} t+\delta Y_{t-1}+\sum_{i=1}^{m} \alpha_{i} \Delta Y_{t-i}+\varepsilon_{i}
$$

Where, $\Delta$ is difference operator, $m$ is the appropriate lag length and $\varepsilon_{i}$ is a white noise disturbance term $Y$, is a variable that is to be tested for unit root and $t$ is the time index.

\subsection{Co-Integration Test}

Once the order of integration is tested, the next step in the ARDL estimation framework is the test of co-integration. The current study employs a bound test approach developed by Pesaran et al. (2001) to examine the variables' long-run association. To this end, the Unrestricted Vector Error Correction Model (UVECM) upon which the test technique depend is specified below as

$$
\begin{aligned}
\Delta & \ln E_{t}=\alpha_{0}+\sum_{i=1}^{p} \alpha_{i} \Delta \ln E_{t-i}+\sum_{i=1}^{p} \alpha_{i} \Delta \ln Y_{t-i}+\sum_{i=1}^{p} \alpha_{i} \Delta \ln S_{t-i}+ \\
+ & \sum_{i=1}^{p} \alpha_{i} \Delta \ln L_{t-i}^{f}+\alpha_{1} \ln E_{t-1}+\alpha_{1} \ln Y_{t-1}+\alpha_{1} \ln S_{t-1}+\alpha_{1} \ln L_{t-1}^{f}+\varepsilon_{1 t} \\
\Delta \ln S_{t}=\alpha_{0}+ & \sum_{i=1}^{p} \alpha_{i} \Delta \ln S_{t-i}+\sum_{i=1}^{p} \alpha_{i} \Delta \ln E_{t-i}+\sum_{i=1}^{p} \alpha_{i} \Delta \ln Y_{t-i}+\sum_{i=1}^{p} \alpha_{i} \Delta \ln L_{t-i}^{f}+ \\
& +\alpha_{1} \ln S_{t-1}+\alpha_{1} \ln E_{t-1}+\alpha_{1} \ln Y_{t-1}+\alpha_{1} \ln L_{t-1}^{f}+\varepsilon_{1 t} \\
\Delta \ln L_{t}^{f}=\alpha_{0}+ & \sum_{i=1}^{p} \alpha_{i} \Delta \ln L_{t-i}^{f}+\sum_{i=1}^{p} \alpha_{i} \Delta \ln E_{t-i}+\sum_{i=1}^{p} \alpha_{i} \Delta \ln S_{t-i}+\sum_{i=1}^{p} \alpha_{i} \Delta \ln Y_{t-i}+ \\
& +\alpha_{1} \ln L_{t-i}^{f}+\alpha_{1} \ln E_{t-1}+\alpha_{1} \ln S_{t-1}+\alpha_{1} \ln Y_{t-1}+\varepsilon_{1 t} \\
& \sum_{i=1}^{p} \alpha_{i} \Delta \ln Y_{t-i}+\sum_{i=1}^{p} \alpha_{i} \Delta \ln E_{t-i}+\sum_{i=1}^{p} \alpha_{i} \Delta \ln S_{t-i}+\sum_{i=1} \alpha_{i} \Delta \ln L_{t-i}^{f}+ \\
& +\alpha_{1} \ln Y_{t-1}+\alpha_{1} \ln E_{t-1}+\alpha_{1} \ln S_{t-1}+\alpha_{1} \ln L_{t-1}^{f}+\varepsilon_{1 t} .
\end{aligned}
$$

Where $p$ is the maximum lag length suggested by information criteria, and they are not necessarily the same for all of the variables and other symbols are as defined before.

\subsection{Granger Causality}

Granger causality test is the third step in the ARDL estimation framework. The test is applied when we have evidence that all of our variables are co-integrated. Furthermore, we should go for this test because the co-integration test provides information about whether there is a logarithm run relationship but not the direction of causality. The foundation for Granger causality is the assumption that a particular variable's past values can influence the other's future value (s). As given in the following vector of the equation, if coefficients of lagged values of independent variables separately are jointly significant, we say our independent variable of interest Granger causes the dependent variable. We should proceed with the test if we are about to argue vice-versa.

$$
\left[\begin{array}{l}
\Delta \ln E_{t} \\
\Delta \ln S_{t} \\
\Delta \ln L_{t}^{f} \\
\Delta \ln Y_{t}
\end{array}\right]=\left[\begin{array}{l}
\theta_{1} \\
\theta_{2} \\
\theta_{3} \\
\theta_{4}
\end{array}\right]+\sum_{i=1}^{p}\left[\begin{array}{l}
\varphi_{11} \varphi_{12} \varphi_{13} \varphi_{14} \\
\varphi_{21} \varphi_{22} \varphi_{23} \varphi_{24} \\
\varphi_{31} \varphi_{32} \varphi_{33} \varphi_{34} \\
\varphi_{41} \varphi_{42} \varphi_{43} \varphi_{44}
\end{array}\right]\left[\begin{array}{c}
\Delta \ln E_{t-i} \\
\Delta \ln S_{t-i} \\
\Delta \ln L_{t-i}^{f} \\
\Delta \ln Y_{-i t}
\end{array}\right]+\left[\begin{array}{c}
\varepsilon_{1} \\
\varepsilon_{2} \\
\varepsilon_{3} \\
\varepsilon_{4}
\end{array}\right]\left[E C T_{t-1}\right]+\left[\begin{array}{l}
\mu_{1 t} \\
\mu_{2 t} \\
\mu_{3 t} \\
\mu_{4 t}
\end{array}\right]
$$

Where, $E C T_{t-1}$ is the lagged Error Correction Term derived from the long run relationship, $\mu_{1 \mathrm{t}}, \mu_{2 \mathrm{t}}, \mu_{3 \mathrm{t}}$, and $\mu_{4 \mathrm{t}}$ are serially uncorrelated disturbance terms. 


\section{Results and Discussions}

\subsection{Unit Root Test}

Table 1 shows that the two-unit root test techniques show that all variables are not stationary at the level. Still, when converted into the first difference, all of them are stationary. So, our variables are integrated of order one or $I(1)$. Thus the ARDL model is estimated with $I(1)$.

The first difference of higher education and labor is checked at the intercept, and also, for the former, lag length three (3) is used in the ADF case.

Table 1. Unit root test

\begin{tabular}{|l|l|l|l|l|l|c|c|c|}
\hline \multicolumn{4}{|c|}{ Augmented Dicky Fuller test } & \multicolumn{4}{c|}{ Phillip Perron test } \\
\hline \multirow{3}{*}{ Variable } & \multicolumn{2}{|c|}{ Level } & \multicolumn{2}{c|}{ First Difference } & \multicolumn{2}{c|}{ Level } & \multicolumn{2}{c|}{ First Difference } \\
\cline { 2 - 9 } & $\begin{array}{c}\text { Test } \\
\text { statistics }\end{array}$ & $\begin{array}{c}\text { Critical } \\
\text { value }\end{array}$ & $\begin{array}{c}\text { Test } \\
\text { statistics }\end{array}$ & $\begin{array}{c}\text { Critical } \\
\text { value }\end{array}$ & $\begin{array}{c}\text { Test } \\
\text { statistics }\end{array}$ & $\begin{array}{c}\text { Critical } \\
\text { value }\end{array}$ & $\begin{array}{c}\text { Test } \\
\text { statistics }\end{array}$ & $\begin{array}{c}\text { Critical } \\
\text { value }\end{array}$ \\
\hline LnRGDP & -0.442 & -3.552 & -3.796 & -3.754 & 0.1005 & -4.262 & -5.824 & -4.103 \\
\hline $\mathrm{LnE}$ & -1.588 & -3.557 & -3.439 & -2.957 & -1.317 & -3.552 & -3.460 & -2.957 \\
\hline $\operatorname{lnS}$ & -2.045 & -3.552 & -7.736 & -3.557 & -1.940 & -3.552 & -14.12 & -3.557 \\
\hline $\operatorname{lnL} \mathrm{f}^{\mathrm{f}}$ & -2.206 & -3.587 & -3.007 & -2.957 & -1.910 & -3.552 & -3.021 & -2.957 \\
\hline
\end{tabular}

\subsection{Co-Integration Test}

Because the result of the unit root test given in table one shows none of the model's variables is not integrated into order 2, it is possible to run the ARDL model because of its aforementioned merits. However, it needs to select the optimal lag length before running the model. For that matter, five selection criteria can guide us to choose the optimal lag length. As has provided in Table 2, three of such selection criteria suggest lag length three. With any maximum lag length imputed, EViews automatically selects the appropriate lag order for each variable. Accordingly, as a result, is given in Figure (1), the stated statistical software has set an ARDL model with specification $(2,3,1,0)$ based on Akaike Information Criteria (AIC). This information criterion used because it is a widely used criterion in ARDL estimation.

Table 2. Lags selection criteria

\begin{tabular}{ccccccc}
\hline \hline Lag & LogL & LR & FPE & AIC & SC & HQ \\
\hline \hline 0 & 19.52589 & NA & $4.32 \mathrm{e}-06$ & -1.001671 & -0.816640 & -0.941355 \\
1 & 248.6317 & 384.3066 & $4.67 \mathrm{e}-12$ & -14.75043 & $-13.82528^{*}$ & -14.44886 \\
2 & 273.2729 & $34.97461^{*}$ & $2.83 \mathrm{e}-12$ & -15.30793 & -13.64266 & -14.76509 \\
3 & 293.3795 & 23.34954 & $2.53 \mathrm{e}-12^{*}$ & $-15.57287^{*}$ & -13.16747 & $-14.78877^{*}$ \\
\hline \hline
\end{tabular}

* indicates lag order selected by the criterion

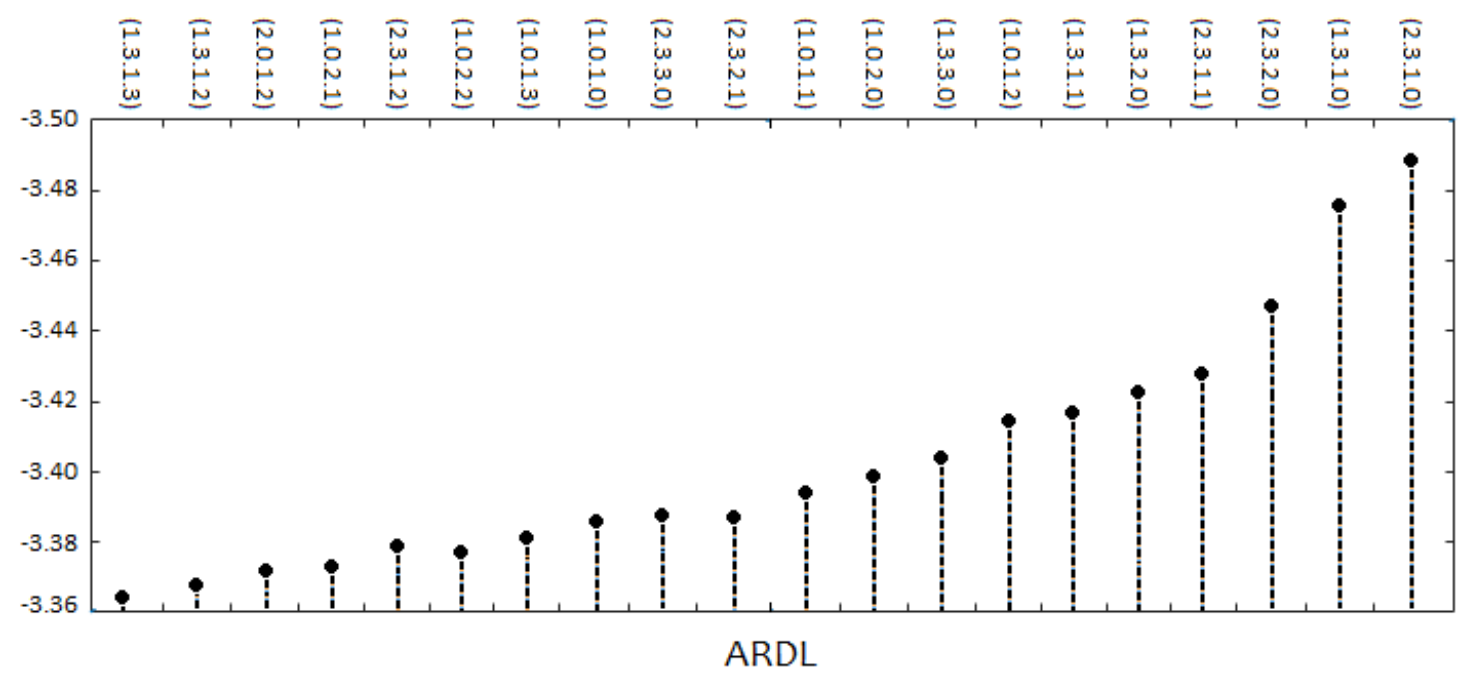

Figure 1. Akaike selection criteria

Using the lag selection criteria, the co-integration test result is shown in Table 3. The name of the test is known as the 
bounds test in the ARDL framework. The test provides F-statistics and upper bound and lowers bound critical values at $1 \%, 2.5 \%, 5 \%$, and $10 \%$. According to the test, three cases should consider to accept or reject the null hypothesis that estates' no long-run relationship exists'. The first case is where F-statistic is less than the lower bound critical value, and if this result happens, the null hypothesis should be accepted. The second case is where the F-statistics is above the upper critical bounds, and in this situation, the null hypothesis should be rejected. As to another possibility, if the F-statistics are found in between the lower and upper bound critical values, the test result is inconclusive. In this study, as shown in Table 3 , the null hypothesis should be rejected, meaning that the model's variables move together in the long run.

Table 3. Co-integration test

\begin{tabular}{lcc}
\hline \hline Test Statistic & Value & $\mathrm{k}$ \\
\hline \hline F-statistic & 11.79662 & 3 \\
\hline \hline
\end{tabular}

Critical Value Bounds

\begin{tabular}{lcc}
\hline \hline Significance & I0 Bound & I1 Bound \\
\hline \hline $10 \%$ & 2.37 & 3.2 \\
$5 \%$ & 2.79 & 3.67 \\
$2.5 \%$ & 3.15 & 4.08 \\
$1 \%$ & 3.65 & 4.66 \\
\hline \hline
\end{tabular}

Once the co-integration exists among the variables, the next step is to examine the error correction term. The error correction term should be negative in sign, between zero and one in the absolute period, and statistically significant. Accordingly, all these requirements met in our model, and the error correction term is -0.5344 , which is statistically significant at a $1 \%$ significance level. The implication is that about $53 \%$ of disequilibrium that occurred in the previous year corrected in the current year.

$$
\text { Cointeq }=\ln R G D P-\left(0.2453 * \ln E+0.4294 * \ln S \quad-0.2109 * \ln L^{f} F+13.7593\right) .
$$

Table 4. Error correction and diagnostic checking

\begin{tabular}{|c|c|c|c|c|}
\hline \multicolumn{5}{|c|}{ Cointegrating Form } \\
\hline Variable & Coefficient & Std. Error & t-Statistic & Prob. \\
\hline $\mathrm{D}(\operatorname{lnRGDP}(-1))$ & 0.175386 & 0.138775 & 1.263810 & 0.2201 \\
\hline $\mathrm{D}(\ln \mathrm{E})$ & 0.046018 & 0.072794 & 0.632161 & 0.5341 \\
\hline $\mathrm{D}(\ln \mathrm{E}(-1))$ & 0.210177 & 0.115043 & 1.826937 & 0.0820 \\
\hline $\mathrm{D}(\ln \mathrm{E}(-2))$ & -0.208796 & 0.074151 & -2.815814 & 0.0104 \\
\hline $\mathrm{D}(\ln S)$ & 0.048382 & 0.040065 & 1.207567 & 0.2406 \\
\hline $\mathrm{D}\left(\operatorname{lnL} \mathrm{f}^{\mathrm{f}} \mathrm{F}\right)$ & -0.112697 & 0.093914 & -1.199997 & 0.2435 \\
\hline CointEq(-1) & -0.534466 & 0.095662 & -5.587007 & 0.0000 \\
\hline \multicolumn{5}{|c|}{ Long Run Coefficients } \\
\hline Variable & Coefficient & Std. Error & $\mathrm{t}$-Statistic & Prob. \\
\hline $\ln E$ & 0.245281 & 0.053843 & 4.555522 & 0.0002 \\
\hline $\ln S$ & 0.429397 & 0.082003 & 5.236364 & 0.0000 \\
\hline $\operatorname{lnL}{ }^{f} F$ & -0.210858 & 0.169470 & -1.244225 & 0.2271 \\
\hline C & 13.759264 & 2.670071 & 5.153146 & 0.0000 \\
\hline
\end{tabular}

As in Table 4, higher education and gross capital formation significantly affect economic growth at $1 \%$. As higher education expansion increased by $1 \%$, real GDP increases by $24 \%$, and a $1 \%$ increase in gross capital formation has an effect of increasing real GDP by $43 \%$. 


\subsection{Diagnostic Checking}

As the test result depicted in Table 5, the model estimated is free from the serial correlation of residuals and is homoscedastic and has a normal distribution. Besides, the model is well specified as guaranteed by the Ramsey RESET Test. The fitted model is also stable as it confirmed by CUSUM and CUSUMQ (Figures 2a, b).

Table 5. Diagnostic checking in CUSUM and CUSUMQ test, solong as the fitted line lies within 5\% critical values, the fitted model is said to be stable.

\begin{tabular}{|l|l|c|c|}
\hline \multicolumn{1}{|c|}{ Diagnostic test } & \multicolumn{1}{|c|}{ Test tecknique applied } & F- statistics & P-value \\
\hline Normality of residuals & Jarque-Bera & 0.71 & 0.7 \\
\hline Serial cirrelation & $\begin{array}{l}\text { Breusch-Godfrey Serial Correlation LM } \\
\text { Test: }\end{array}$ & 0.56 & 0.57 \\
\hline Heteroscedasticity & Breusch-Pagan-Godfrey & 0.82 & 0.6 \\
\hline Functional form & Ramsey RESET Test & 0.007 & 0.92 \\
\hline
\end{tabular}
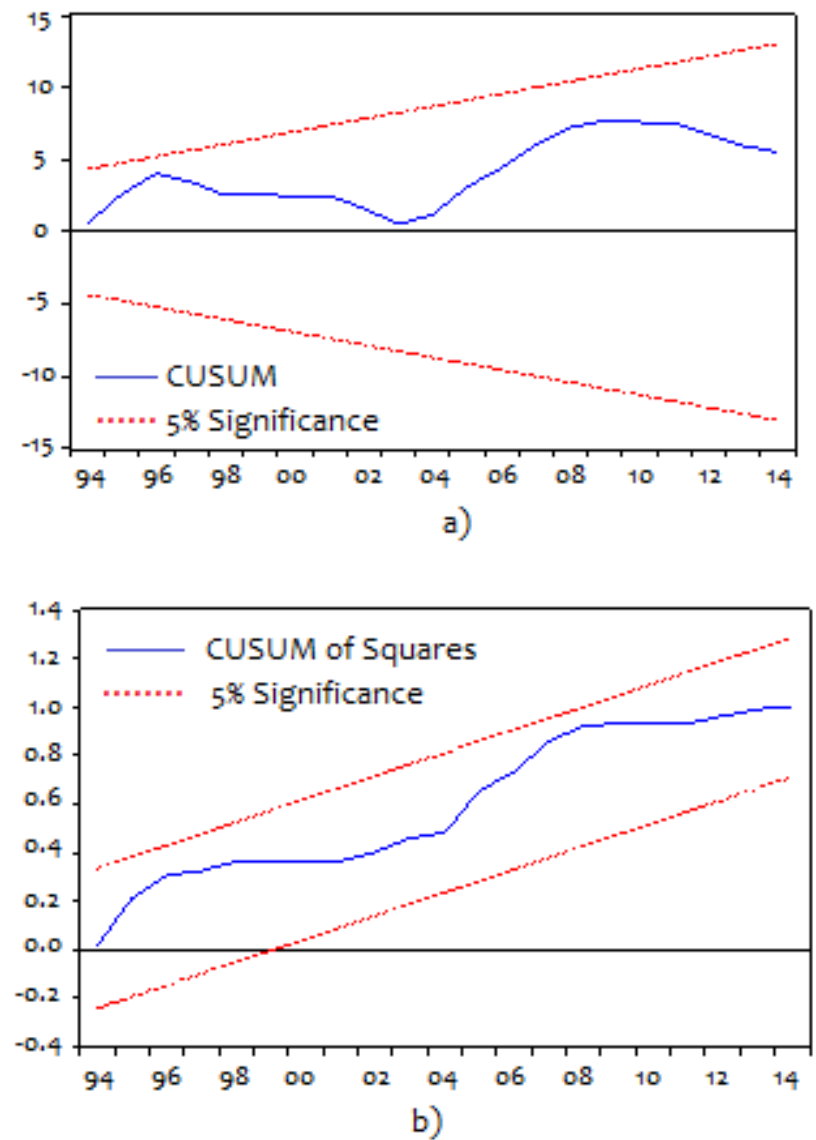

Figure 2. Stability test

\subsection{Granger Causality}

In Granger causality, the null hypothesis states there is no causality. Therefore, if the probability value is greater than 0.05 , we cannot reject the null hypothesis and conclude no causality between variables. If the probability value is less than 0.05 , we cannot accept the null hypothesis and conclude that there is causality. As indicated in Table 6 , there is a unidirectional causality running from higher education to economic growth, and bidirectional causality between gross capital formation and economic growth. This result disproves the prior hypothesis, which states there is no reciprocal causality between higher education and economic growth. 
Table 6. Granger Causality Test

\begin{tabular}{|c|c|c|c|}
\hline Null Hypothesis: & Obs & F-Statistic & Prob. \\
\hline lnE does not Granger Cause lnRGDP & \multirow[t]{2}{*}{31} & 3.50358 & 0.0308 \\
\hline lnRGDP does not Granger Cause $\ln E$ & & 1.14430 & 0.3513 \\
\hline lnS does not Granger Cause lnRGDP & \multirow[t]{2}{*}{31} & 9.51563 & 0.0003 \\
\hline lnRGDP does not Granger Cause $\ln S$ & & 5.52528 & 0.0050 \\
\hline $\ln L^{f} F$ does not Granger Cause lnRGDP & \multirow[t]{2}{*}{31} & 1.25629 & 0.3116 \\
\hline $\operatorname{lnRGDP}$ does not Granger Cause $\operatorname{lnL}{ }^{\mathrm{f}} \mathrm{F}$ & & 1.56488 & 0.2238 \\
\hline $\ln S$ does not Granger Cause $\ln E$ & \multirow[t]{2}{*}{31} & 1.77094 & 0.1796 \\
\hline $\ln E$ does not Granger Cause $\ln S$ & & 2.72766 & 0.0663 \\
\hline $\operatorname{lnL}{ }^{f} F$ does not Granger Cause $\ln E$ & \multirow[t]{2}{*}{31} & 1.95497 & 0.1477 \\
\hline $\operatorname{lnE}$ does not Granger Cause $\operatorname{lnL}{ }^{\mathrm{f}} \mathrm{F}$ & & 4.95731 & 0.0081 \\
\hline $\ln L^{f} F$ does not Granger Cause $\ln S$ & \multirow[t]{2}{*}{31} & 2.73733 & 0.0657 \\
\hline $\ln S$ does not Granger Cause $\ln L^{f} F$ & & 0.74105 & 0.5380 \\
\hline
\end{tabular}

\section{Conclusion and Recommendation}

Vietnam government has paid great attention to higher education expansion, and hence, it has been a national policy issue of the country. While doing this, the sector's expectation on the part of the government is that it will help achieve the country's development dream. However, some empirical evidence from across the world asserts the nonexistence of the causal relationship between higher education and economic growth. If the same holds for Vietnam, it means that the government's investment in higher education expansion is simply wastage and out to be diverted to other productive investments. Thus, the aim of the current study was an assessment of the causal relationship between them. To this end, the time-series data period 2010 - 2019 collected on four variables: real GDP, enrollment in higher education, gross capital formation, and labor. Appropriate methodological procedures in light of available literature applied to the analysis of the data. Accordingly, the ARDL model's estimation justified based on unit root test results and the superiority of the model over other competing models. The abounds test approach associated with ARDL run to investigate the long-run relationship between the four variables. From the test result, it observed that those variables have a long-run relationship. The Granger causality test was employed to examine the causal relationship between higher education and economic growth, and it confirmed unidirectional causality running from higher education to economic growth. Therefore, based on the study's output, the author recommends that the government continue higher education's energetic effort.

\section{Acknowledgement}

The authors thank VNU University of Education, the University of Tan Trao for support and have heartfelt gratitude to all data sources.

\section{Conflict of interest}

The author, declare that there is no conflict of interest with regards to this manuscript.

\section{Reference}

Becker, G. S. (2009). Human capital: A theoretical and empirical analysis, with special reference to education. University of Chicago press.

Behroozni, A., Shafizadeh, R., Laalbar, A., \& Karsalari, A. R. (2016). Human Capital and Economic Growth in Asian Countries. International Journal of Academic Research in Accounting, Finance and Management Sciences, 6(1), 1. https://doi.org/10.6007/IJARAFMS/v6-i1/1930

Bergheim, S. (2005). Current Issues: Global Growth Centre. (Ed. Stefan Schneider). Deutsche Bank Research, 1-32. https://doi.org/10.2139/ssrn.698141

Bils, M., \& Klenow, P. J. (1998). Does schooling cause growth or the other way around? (No. w6393). National Bureau of Economic Research. https://doi.org/10.3386/w6393

Dang, D. A. (2019). Vietnam's economic prospects for the period 2021-2025: Opportunities and challenges from 
new-generation free trade agreements. Annual International Scientific Conference 2019, Hanoi, Vietnam.

Devadas, U. (2015). Comprehensive Literature Review on Human Capital Investments Theory: What's in it?. Kelaniya Journal of Human Resource Management, 10(1-2). https://doi.org/10.4038/kjhrm.v10i1-2.19

Dickey, D. A., \& Fuller, W. A. (1979). Distribution of the estimators for autoregressive time series with unit root. Journal of the American Statistical Association, 74, 427-431. https://doi.org/10.2307/2286348

GDP - World Development Indicators: Structure of output (2019). Retrieved from: http://wdi. worldbank.org/table/4.2.

Hanushek, A. E., \& Woessmann, L. (2007). Education Quality and Economic Growth. The World Bank, Washington, DC, 27p. https://doi.org/10.1596/1813-9450-4122

Horii, R. A., Kitagawa, A., \& Futagami, K. (2007). Availability of Higher Education and Long-Term Economic Growth. The Japanese Economic Review (OnlineEarly Articles), 2, 156-177. https://doi.org/10.1111/j.1468-5876.2007.00403.x

Lucas, R. (1988). On the Mechanics of Economic Development. Journal of Monetary Economics, 22(1), 3-42. https://doi.org/10.1016/0304-3932(88)90168-7

Nguyen, D. H. (2020) A review of issues of quality assurance and quality accreditation for higher education institutions and the situation in Vietnam. Accreditation and Quality Assurance, 25, 273-279. https://doi.org/10.1007/s00769-020-01439-3

Nkoro, E., \& Uko, K. A. (2016). Autoregressive Distributed Lag (ARDL), co-integration technique: application and interpretation. Journal of Statistical and Econometric Methods, 5(4), 63-91.

Pesaran, M. H., Shin, Y., \& Smith, R. J. (1996). Testing for the' Existence of a Long-run Relationship. Faculty of Economics, University of Cambrdge.

Pesaran, M. H., Shin, Y., \& Smith, R. J. (2001). Bounds testing approaches to the analysis of level relationships. Journal of Applied Econometrics, 16(3) 289-326. https://doi.org/10.1002/jae.616

Pritchett, L. (2001). Where all education has gone. The World Bank Economic Review, 15(3), 367-391. https://doi.org/10.1093/wber/15.3.367

Romer P. M. (1988) Capital accumulation in the theory of long run growth. Barro, R. J. (ed.) Harvard University Press. 51-127.

Rusli, N. A. M., \& Hamid, Z. (2014). Human capital and economic growth: Empirical evidence from Malaysia. Lumban Gaol et al. (Eds). Recent Trends in Social and Behaviour Sciences 6, eBook ISBN9780429227387.

Solow, R. M. (1956). A contribution to the theory of economic growth. Quarterly Journal of Economics, 70, 65-94. https://doi.org/10.2307/1884513

Temple, J. (1999). The New Growth Evidence. J. Econ. Lit., 1, 112-156. https://doi.org/10.1257/jel.37.1.112

Thuy, L. (2017). How is the 1979 training plan different from the current new program? Giaoduc.net. Retrieved from https://giaoduc.net.vn/giao-duc-24h/ke-hoach-dao-tao-nam-1979-khac-gi-voi-chuong-trinh-moi-hien-tai-post17916 5.gd

UNESCO. (2019). Enrolment Numbers And Gross Enrolment Ratio at Tertiary Level by Country And Gender. UNESCO Institute for Statistics.

World Bank Group. (2017). Higher Education for Development An Evaluation of the World Bank Group's Support. 1818 H Street NW Washington, DC 20433.

World Bank Group (2019). https://data.worldbank.org/indicator/NY.GDP.MKTP.CD.

\section{Copyrights}

Copyright for this article is retained by the author(s), with first publication rights granted to the journal.

This is an open-access article distributed under the terms and conditions of the Creative Commons Attribution license (http://creativecommons.org/licenses/by/4.0/). 